\title{
Dampak Belajar Dari Rumah (BDR) pada Masa Pandemi Covid-19 terhadap Kemampuan Literasi Membaca Anak Usia Dini
}

\author{
Arlis Muryani, Akhmad Khusni Mubaroq, Maria Denok Bekti Agustiningrum \\ Prodi Pendidikan Guru Pendidikan Anak Usia Dini, Fakultas Keguruan dan Ilmu Pendidikan, \\ Universitas IVET, Indonesia
}

\begin{tabular}{l}
\hline Info Articles \\
\hline Sejarah Artikel: \\
Disubmit 22 Januari 2022 \\
Direvisi 30 Januari 2022 \\
Disetujui 30 Januari 2022 \\
\hline Keywords: \\
Early Childhood; \\
Learning From Home (LFH); \\
Pandemic Covid-19; \\
Reading Literacy;
\end{tabular}

\section{Keywords:}

hood;

Pandemic Covid-19,

Reading Literacy 


\section{PENDAHULUAN}

Pandemi Covid-19 menjadi keadaan luar biasa yang membawa perubahan signifikan dalam berbagai bidang. Dunia pendidikan merupakan salah satu bidang yang terkena imbas dari Covid-19. Menyikapi hal tersebut, Menteri Pendidikan dan Kebudayaan (Mendikbud) Nadiem Makarim mengeluarkan Surat Edaran (SE) Mendikbud RI Nomor 3 Tahun 2020 pada 9 Maret 2020 tentang instruksi pencegahan Covid-19 pada satuan pendidikan. Selanjutnya Mendikbud kembali mengeluarkan Surat Edaran Mendikbud RI Nomor 4 Tahun 2020 tentang Pelaksanaan Pendidikan dalam Masa Darurat Corona Virus Disease (Covid-19) yang diperkuat dengan SE Sekjen Nomor 15 tahun 2020 tentang Pedoman Pelaksanaan BDR selama Darurat Covid-19. Pelaksanaan pendidikan ini bernama Belajar Dari Rumah (BDR) atau Learning From Home (LFH).

BDR merupakan kegiatan pembelajaran yang dilaksanakan dari rumah dengan bantuan media berupa perangkat elektronik HP android, komputer, dan jaringan internet. Pembelajaran ini dilakukan dalam jaringan (daring) atau online menggunakan platform, aplikasi, maupun jejaring sosial tertentu. Ada dua jenis sistem pembelajaran ini, yaitu sinkron dan asinkron. Daring sinkron merupakan jenis interaksi pembelajaran secara langsung (tatap maya) dan bersifat dua arah. Sementara daring asinkron merupakan interaksi pembelajaran secara tidak langsung (tidak tatap maya) dan bersifat satu arah. BDR diharapkan dapat mendukung proses pembelajaran jarak jauh dan mempermudah dalam penyebaran materi kepada peserta didik (Kurniasari et. al. 2020).

Menindaklanjuti Surat Edaran tersebut, Pemerintah Kota Semarang memberlakukan BDR pada semua jenjang pendidikan mulai dari PAUD sampai perguruan tinggi. Pelaksanaannya diawali tanggal 23 Maret 2020 sampai 31 Maret 2020. Kemudian setelah itu terus diperpanjang dalam kurun waktu tertentu sampai kondusif. BDR di Kota Semarang didasarkan atas Surat Edaran Kadinas Pendidikan Kota Semarang Tentang Layanan Penyelenggaraan Pendidikan Dalam Rangka Pencegahan Penularan Dan Penyebaran Covid-19 Di Kota Semarang 26 Maret 2020. Pendidikan Anak Usia Dini (PAUD) sebagai tingkat pendidikan dasar ikut melaksanakan BDR. Akan tetapi dalam pelaksanaanya, tidak semudah membalikkan telapak tangan dan tidak sedikit menyisakan masalah. Masalah-masalah yang muncul antara lain (1) keberadaan guru dan peserta didik tidak bertemu secara langsung di dalam satu tempat seperti kegiatan pembelajaran tatap muka; (2) peserta didik kurang bisa memahami materi dengan baik, (3) penyampaian materi oleh guru kurang maksimal karena tidak di depan peserta didik, (4) guru terkesan hanya memberikan tugas kepada peserta tidak, (5) peserta didik terlambat/tidak mengumpulkan tugas, dan (5) kurangnya pendampingan orangtua atau pengasuh pada waktu pembelajaran (AUD masih membutuhkan orangtua, pengasuh, atau orang dewasa untuk melaksanakan BDR). Prasetyaningtyas (2020) menambahkan bahwa pelaksanaan BDR memang tidak mudah. Ditemukan hal yang tidak menyenangkan dalam pelaksanaan BDR antara lain (1) pembelajaran dirasa membosankan, (2) motivasi belajar siswa kurang, (3) terlalu banyak tugas, (4) kurang fokus dalam belajar, dan (5) suasana yang kurang menyenangkan.

Sama halnya dengan pelaksanaan BDR di PAUD, Rahmasari dan Anita (2020) memperkuat temuan Prasetyaningsih bahwa terdapat beberapa hal yang tidak menyenangkan saat BDR bagi anak TK. Beberapa hal itu seperti (1) menurunnya tingkat kedisiplinan anak, (2) motivasi belajar siswa sedikit, (3) kurang fokus dalam menyelesaikan kegiatan belajar, (4) dan suasana pembelajaran kurang menyenangkan. Dari empat tersebut, tingkat kedisiplinan mengalami penurunan drastis. Penurunan kedisiplinan anak TK ditandai dengan bangun siang dan tidak melaksanakan kegiatan sehari-hari sesuai dengan waktunya.

Menurut Makarim (2020) penyelenggaraan BDR tidak semata-semata ditujukan untuk mengejar ketuntasan kurikulum tetapi juga menekankan pada kompetensi literasi dan numerasi. Kompetensi literasi perlu dikenalkan pada anak usia dini (AUD). Kemampuan literasi pada AUD adalah kemampuan membaca dan menulis sebelum anak benar-benar mampu membaca dan 
menulis. Kemampuan ini diawali dengan pengalaman literasi membaca yang dilakukan secara bertahap dengan memperhatikan tahap perkembangan anak.

Hasil penelitian Dunphy (2012) menjelaskan bahwa pengalaman literasi dapat membantu belajar kemampuan membaca dan menulis. Apabila anak memiliki pengalaman literasi maka anak akan dapat dengan mudah belajar membaca dan menulis sehingga berdampak pada pencapaian akademik yang lebih baik. Seperti halnya Dunphy, Prioletta dan Pyle (2017) juga meneliti tentang pengalaman literasi. Mereka menemukan hal yang dapat mendukung pengalaman literasi anak secara konkret. Hal tersebut antara lain (1) adanya ketersediaan sumber bacaan lisan maupun tulisan di lingkungan bermain dan (2) ketersediaan sumber bacaan tersebut dapat diintegrasikan dengan permainan melalui kegiatan menulis, menggambar, dan bermain drama.

Praktik literasi membaca pada jenjang PAUD bisa ditemukan pada sentra keaksaraan. Mengacu pada hal tersebut, ditemukan fakta yang tidak sesuai dengan praktik literasi pada AUD, yaitu AUD membaca dengan duduk rapi berhadapan langsung dengan buku. Kegiatan ini sama seperti praktik literasi membaca yang diselenggarakan pada jenjang SD, SMP, dan SMA. Hal ini justru menjadikan AUD merasa terbebani dan terpaksa sehingga jauh dari cara menyenangkan, berlangsung tanpa paksaan, dan ramah anak. Seharusnya praktik literasi membaca AUD disampaikan dengan memperhatikan tugas-tugas perkembangan, keunikan anak, konsep menumbuhkan pengalaman yang telah dikonstruksi dan dimiliki anak sejak lahir (Fauziah 2019). Memperkuat hasil penelitian Fauziah, idealnya praktik literasi dilakukan dengan cara yang menyenangkan, berlangsung tanpa paksaan, dan ramah anak (Nurhasanah 2020:182).

Indonesia sendiri masih memiliki banyak permasalahan terkait dengan minat baca, rendahnya minat baca di Indonesia tercermin dari beberapa fakta yang memuat tentang prestasi bangsa Indonesia dibandingkan dengan negara-negara lain. Berdasar hasil survei Program for International Student Assesment (PISA) tahun 2019 berkaitan dengan tingkat literasi bahwa Indonesia menduduki rangking 62 dari 70 negara. Indonesia berada pada 10 negara terbawah yang memiliki tingkat literasi rendah (Utami 2021). Dilihat dari minat baca masyarakat Indonesia dapat dikatakan masih sangat rendah. Menurut Suyoto (2010) rendahnya minat baca masyarakat Indonesia juga bisa dibuktikan dari indeks membaca yang baru sekitar 0,0001. Artinya dari 1000 penduduk hanya satu orang yang memiliki minat baca. Dengan demikian, Indonesia diklaim sebagai negara yang rendah minat dan budaya baca sekaligus rendah pula indeks literasinya.

Mengingat kemampuan literasi membaca memiliki peran penting, yaitu menyiapkan Sumber Daya Manusia (SDM) yang unggul dan mengantarkan kemajuan suatu negara maka kemampuan literasi membaca dapat diperkenalkan sejak AUD. Anak usia dini adalah anak yang berada pada rentan usia 0-6 tahun (Undang-Undang Sisdiknas No 20 tahun 2003). Suyadi (2017) mengatakan bahwa anak usia dini merupakan kelompok usia anak yang berada dalam proses pertumbuhan dan perkembangan yang biasa disebut masa golden age (masa emas). Periode emas merupakan masa otak anak mengalami perkembangan paling cepat mencapai $80 \%$.

Berdasarkan UU No 146 Tahun 2014 tentang standar pembelajaran anak usia dini meliputi enam aspek perkembangan diantaranya fisik dan motorik, kognitif, seni, sosial-emosional, agama dan moral serta literasi atau bahasa. Ke enam aspek ini yang akan mengalami perkembangan sesuai pada tahapan anak usia dini. Berkaitan dengan aspek bahasa, wayang sebagai salah satu media yang memiliki kearifan lokal jawa mampu menjadi salah satu alternatif media yang dapat menstimulasi penyelesaian tugas perkembangan kemampuan berbahasa anak usia 5-10 tahun (Agustiningrum 2018). Wayang dapat diadikan sebagai media dalam proses pemerolehan bahasa yang bertujuan menstimulus perkembangan bahasa anak. Temuan penelitian ini mendukung standar pembelajaran aspek perkembangan bahasa dan meningkatkan perkembangan bahasa anak sesuai tahapan usia anak. Dengan perkembangan yang sesuai, dapat dikatakan capaian pembelajaran anak di PAUD terbayar tuntas dan dijadikan sebagai bekal pengetahuan untuk memasuki jenjang pendidikan dasar. 
Berdasarkan uraian tersebut mengarahkan peneliti untuk mengetahui dampak BDR terhadap kemampuan literasi membaca AUD yang dirasakan selama pandemi Covid-19. Tujuan penelitian ini untuk mengetahui sejauh mana peran guru, orang tua dalam memahami BDR, mendampingi proses BDR, dan mengetahui dampak adanya BDR terhadap kemampuan literasi membaca AUD. Hasil penelitian ini diharapkan guru, orang tua, dan berbagai pihak yang berada di lingkungan sekitar anak usia dini dapat mengetahui dan memahami adanya dampak BDR. Semuanya dapat bekerja sama mengurangi dampak BDR terhadap kemampuan literasi membaca AUD sehingga AUD dapat melaksanakan BDR dengan menyenangkan dan tanpa paksaan.

\section{METODE}

Pendekatan dan jenis yang digunakan dalam penelitian ini adalah pendekatan kualitatif desktiptif. Pendekatan ini menurut Sukmadinata (2012:18) adalah suatu penelitian yang ditunjukkan untuk menggambarkan suatu objek atau suatu keadaan dan fenomena-fenomena dengan apa adanya. Objek atau keadaan dan fenomena yang dideskripsikan dalam penelitian ini yaitu dampak yang ditimbulkan dengan adanya BDR terhadap kemampuan literasi membaca anak usia dini. Penelitian ini bertujuan untuk mendeskripsikan dampak apa saja yang dialami anak usia dini pada masa pandemi Covid-19 terhadap kemampuan literasi membaca. Subjek penelitian yang digunakan dalam penelitian ini adalah lima guru dan tiga puluh orang tua peserta didik kelas B usia 5-6 tahun di TK IT Al-Hikmah 2 Semarang. Teknik pengumpulan data yang digunakan adalah dengan gabungan triangulasi dan angket. Wawancara dan angket dibagikan kepada subjek penelitian. Pengisian dilakukan dengan cara membagikan angket kepada guru TK dan orang tua peserta didik pada Mei-Juni 2021 berdasarkan pengamatan orang tua selama mengikuti BDR.

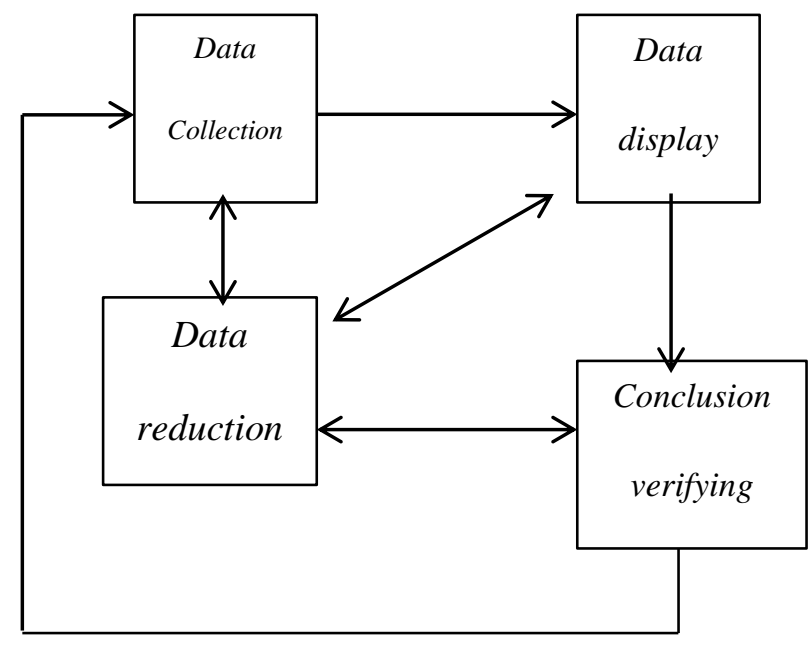

Gambar 1.1 Komponen Analisis Data (interactive model)

Data penelitian ini dianalisis menggunakan analisis deskriptif dengan pendekatan kualitatif yang meliputi mengumpulkan, menulis, menganalisis, dan menyimpulkan data. Hal ini bertujuan agar hasil analisis dapat dijabarkan secara mendalam dan terperinci. Dengan merujuk analisis model interaktif Miles and Huberman (1992), dalam menganalisis data peneliti mengaitkan kegiatankegiatan analisis satu sama lain. Analisis diawali dengan kegiatan koleksi data, reduksi data, penyajian data, dan diakhiri dengan penarikan simpulan. 


\section{HASIL DAN PEMBAHASAN}

\section{A. Pelaksanaan BDR}

Pelaksanaan BDR di TK IT Al-Hikmah 2 Semarang sudah sesuai dengan SE dari Mendikbud RI dan dari Dinas Pendidikan dan Kebudayaan Kota Semarang. Berdasar surat tersebut sekolah membuat surat pemberitahuan kepada orang tua/wali murid yang berisi bahwa pembelajaran dilakukan BDR secara daring dalam kurun waktu tertentu. Sebagai persiapan BDR setiap guru melakukan kegiatan antara lain (1) guru membuat Rencana Pelaksanaan Pembelajaran Mingguan (RPPM) dan Rencana Pelaksanaan Pembelajaran Harian (RPPH) yang disesuaikan dengan pembelajaran BDR, (2) guru melakukan pendataan kepada orang tua yang memiliki HP android sebagai sarana pembelajaran, (3) BDR dilakukan guru dengan menggunakan HP android melalui aplikasi WhatsApp $(W A)$.

Komponen-komponen dalam RPPH sesuai dengan RPPH pembelajaran regular tetapi pelaksanaan pembelajaran BDR secara daring. Langkah pembelajaran, alat, dan bahan tentunya disesuaikan dengan yang tersedia di rumah. Proses pelaksanaan BDR di TK IT Al-Hikmah 2 Semarang menggunakan tiga sistem, yaitu sikron, asikron, dan orang tua datang ke sekolah. Sistem sikron dilaksanakan melalui WhatsApp (WA) menu Video Call (VC), sedangkan sistem asinkron dilaksanakan melalui $W A$ Group $(W A G)$. Sementara sistem orang tua datang ke sekolah dilaksanakan ketika pembagian tugas dan pengumpulan tugas dari Lembar Kerja Anak (LKA).

Pada awal-awal pembelajaran berlangsung, peserta didik TK B memberikan partisipasi yang bagus. Hal ini bisa dilihat dari semangat dan motivasi belajar yang tinggi serta pengumpulan tugas tepat waktu. Setelah sembilan bulan pelaksanaan BDR, kondisi ini menurun maka peneliti membagikan angket kepada orang tua peserta didik. Angket ini berisi tanggapan orang tua terkait pelaksanaan BDR terhadap kemampuan literasi membaca anak usia dini dan dampaknya. Sebanyak tiga puluh orang tua mengisi angket tersebut. Hasil angket tersebut tertera pada Tabel 1 berikut.

Tabel 1. Hasil Angket Tanggapan Orang Tua Dampak BDR Terhadap Kemampuan Literasi Membaca Anak Usia Dini

\begin{tabular}{|c|c|c|}
\hline No & Pernyataan & Persentase \\
\hline 1. & $\begin{array}{l}\text { Ketersediaan perangkat teknologi informasi di rumah dapat mendukung } \\
\text { BDR. }\end{array}$ & $91,6 \%$ setuju \\
\hline 2. & Peserta didik memerlukan pendampingan orang tua selama BDR. & $87,5 \%$ setuju \\
\hline 3. & $\begin{array}{l}\text { BDR memerlukan suasana yang menyenangkan, keadaan jiwa, dan } \\
\text { suasana hati anak baik. }\end{array}$ & $95,8 \%$ setuju \\
\hline 4. & Pengenalan literasi membaca bisa menggunakan objek nyata. & $83,3 \%$ setuju \\
\hline 5. & $\begin{array}{l}\text { Orang tua kesulitan menumbuhkan motivasi dan minat baca selama } \\
\text { BDR. }\end{array}$ & $91,6 \%$ setuju \\
\hline 6. & Orang tua dan anak membaca bersama. & $45,8 \%$ setuju \\
\hline 7. & $\begin{array}{l}\text { Ketika orang tua tidak mengikuti arahan dan materi yang diberikan guru } \\
\text { maka pelaksanaan BDR akan terganggu. }\end{array}$ & $50,0 \%$ setuju \\
\hline 8. & BDR membuat anak memiliki kegiatan dan pikiran positif. & $79,1 \%$ setuju \\
\hline 9. & BDR membuat anak cepat marah, merasa bosan, dan kecanduan hp. & $66,6 \%$ setuju \\
\hline 10 . & BDR membuat anak tetap dekat dengan teman dan gurunya. & $54,1 \%$ setuju \\
\hline
\end{tabular}

Tabel 1. menunjukkan ada tiga hal utama, yaitu BDR, kemampuan literasi membaca, dan dampak BDR yang mempengaruhi kemampuan literasi membaca anak usia dini. Pertama tentang BDR bahwa dalam pelaksanaanya diperlukan ketersediaan perangkat teknologi informasi di rumah seperti hp android, laptop, jaringan internet yang stabil. Pendampingan orang tua dalam BDR juga sangat dibutuhkan. Pendampingan sangat diperlukan anak usia dini karena mereka belum bisa 
menggunakan hp secara mandiri. BDR dilaksanakan dengan suasana yang menyenangkan. Kedua tentang kemampuan literasi membaca anak usia dini. yang perlu dilakukan orang tua dalam mendampingi anak melaksanakan BDR. Pencapaian kemampuan ini didapatkan peserta didik sebagian sudah berkembang sesuai harapan dan sebagian lagi belum berkembang sesuai harapan. Bagi anak usia dini yang kemampuan literasi membaca sudah berkembang sesuai harapan ini merupakan bukti adanya pendampingan dan dukungan orang tua dalam melaksanakan BDR melalui beberapa cara seperti membaca dengan objek nyata dan kegiatan membaca bersama. Akan tetapi, orang tua juga menemukan kendala menumbuhkan motivasi dan minat baca selama BDR. Untuk menumbuhkan minat baca anak usia dini orang tua dapat melakukan kegiatan home literacy. Kegiatan ini merupakan kegiatan belajar di rumah (menempel poster di dinding, mengenalkan keaksaraan, menyediakan APE) yang dapat membantu anak dalam menyiapkan kemampuan awal membaca. Ketiga tentang dampak BDR yang dirasakan peserta didik selama melaksanakan BDR.

Beberapa kendala muncul seperti jaringan internet yang tidak stabil, peserta didik merasa jenuh mengikuti BDR, dan pendampingan orang tua yang kurang dapat memicu penurunan ketercapaian materi. Untuk mengatasi kendala-kendala tersebut diperlukan strategi untuk mengodusifkan pelaksanaan BDR seperti:

1. guru menjalin komunikasi yang baik dengan orang tua;

2. guru melaporkan pencapaian peserta didik dalam setiap aspek perkembangan;

3. guru menciptakan suasana BDR yang menyenangkan;

4. orang tua dapat menstimulus minat baca menggunakan kegiatan "home literacy" dan pengalaman literasi yang menyenangkan;

5. bagi orang tua yang memiliki kesibukan bekerja diharapkan bisa mengatur waktu untuk mendampingi mengikuti BDR.

\section{B. Dampak BDR terhadap Kemampuan Literasi Membaca}

Pelaksanaan BDR menimbulkan dampak positif dan negatif bagi anak usia dini. Dampak positif bagi peserta didik khususnya terhadap kemampuan literasi membaca antara lain (1) adanya pendampingan belajar membaca dari orang tua kepada anak, (2) peserta didik memiliki kegiatan dan pikiran positif, (3) orang tua lebih berperan dalam ketercapaian belajar anak, (4) adanya kegiatan literasi membaca bersama antara orang tua dan anak dapat meningkatkan keharmonisan keluarga, dan (5) komunikasi anak dan orang tua terjalin dengan baik. Sementara itu, dampak negatif yang dirasakan peserta didik antara lain (1) anak cepat marah dan merasa bosan, (2) anak kecanduan hp, (3) anak merasa sendirian karena tidak ada sosialisasi dengan teman, (4) anak kurang disiplin, (5 ) penurunan kemampuan literasi membaca anak karena minat baca yang rendah, dan (6) belum tercapainya tujuan pembelajaran akibat pendampingan yang kurang bagi orang tua yang memiliki kesibukan tertentu.

\section{SIMPULAN}

Berdasarkan kajian tersebut, pelaksanaan BDR terhadap kemampuan literasi membaca anak usia dini memberi dampak yang signifikan. Pelaksanaan BDR tersebut menimbulkan sejumlah dampak diantaranya: (1) kompetensi guru dalam penggunaan teknologi dan kolaborasi yang baik antara peserta didik, guru, dan orang tua sangat mempengaruhi kualitas BDR; (2) jenis stimulus yang diberikan orang tua mempengaruhi kemampuan literasi membaca anak; (3) pengetahuan orang tua tentang literasi membaca akan mempengaruhi keragaman kegiatan perkembangan bahasa; dan (4) dampak positif dan negatif dari pelaksanaan BDR terhadap kemampuan literasi membaca anak usia dini dapat dijadikan kajian evaluasi dalam pelaksanaan BDR pada anak usia dini. 


\section{DAFTAR PUSTAKA}

Agustiningrum, Maria Denok Bekti. 2018. "Penggunaan Metode Audio-Lingual dalam Proses Belajar Mendalang sebagai Pemenuhan Fungsi Bahasa Anak Usia 5-10 Tahun (Studi Kasus Dalang Cilik)". Prosiding Seminar Nasional Bulan Bahasa 1: Menduniakan Bahasa dan Sastra Indonesia. Disampaikan pada Seminar Bulan Bahasa 1 Universitas PGRI Semarang. Semarang: 7 November 2018.

Dunphy, E. 2012. "Children's Participation Rights in Early Childhood Education and Care: The Case of Early Literacy Learning and Pedagogy". International Journal of Early Years Education, 20 (3), 290-299. https://doi.org/10.1080/09669760.2012.716700. Diunduh 31 Maret 2021.

Fauziah, Syifa. 2019. "Optimalsasi Manajemen Pembelajaran di PAUD Semai Benih Bangsa Pelangi Nusantara 05 Kabupaten Semarang". Indonesian Journal Of Early Chilhood: Jurnal Dunia Anak Usia Dini. http://jurnal.unw.ac.id:1254/index.php/IJEC/article/view/353. Diunduh 31 Maret 2021.

Kurniasari, A., Pribowo, F. S. P., \& Putra, D. A. 2020. "Analisis Efektivitas Pelaksanaan Belajar Dari Rumah (BDR) Selama Pandemi Covid-19”. Jurnal Review Pendidikan Dasar: Jurnal Kajian Pendidikan dan Hasil Penelitian, 6 (3), 246-253. https://journal.unesa.ac.id/index.php/PD/article/view/10423. Diunduh 31 Maret 2021.

Makarim, Nadiem. 2020. "Penyelenggaraan Pendidikan di Masa Pandemi Covid-19". https://id.wikipedia.org/wiki/Belajar dari Rumah. Diunduh 30 Maret 2021.

Miles, M.B. dan Huberman, A.M. 1992. Analisis Data Kualitatif (Terjemahan Tjetjep Rohendi Rohidi). Jakarta: UI Press.

Permendikbud Nomor 146 Tahun 2014 Tentang Kurikulum 2013 PAUD. https://anggunpaud.kemdikbud.go.id. Diunduh 9 April 2021.

Prasetyaningtyas, Susi. "Pelaksanaan Belajar Dari Rumah (BDR) Secara Online Selama Darurat Covid-19 di SMP N 1 Semin". Ide Guru: Jurnal Karya Ilmiah Guru 5 (1), hal 86-94. https://iurnal-dikpora.jogiaprov.go.id/index.php/iurnalideguru/article/view/139.

Diunduh 31 Maret 2021.

Prioletta, J., \& Pyle, A. 2017. "Play and Gender in Ontario Kindergarten Classrooms: Implications for Literacy Learning". International Journal of Early Years Education, 25 (4), 393-408. https://doi.org/10.1080/09669760.2017.1390446. Diunduh 31 Maret 2021.

Rahmasari dan Anita. 2020. "Analisis Dampak Learning Fom Home pada Masa Pandemi Covid-19 terhadap Kedisiplinan Anak Usia 5-6 Tahun di TK Islam Al Fath Semarang”. Prosiding Konferensi Ilmiah Unissula (KIMU) hal 364-37). http://lppmunissula.com/jurnal.unissula.ac.id/index.php/kimuhum/article/view/13012. Diunduh 31 Maret 2021.

Sukmadinata, Nana Syaodih. 2012. Metode Penelitian Pendidikan. Bandung: Remaja Rosdakarya.

Surat Edaran Menteri Pendidikan dan Kebudayaan RI Nomor 3 Tahun 2020 tentang Instruksi Pencegahan Covid-19 pada Satuan Pendidikan. https://www.kemdikbud.go.id/main/blog/2020/03/surat-edaran-pencegahan-covid19pada-satuan-pendidikan. Diunduh 30 Maret 2021. 
Surat Edaran Menteri Pendidikan dan Kebudayaan RI Nomor 4 Tahun 2020 tentang Pelaksanaan Kebijakan Pendidikan dalam Masa Darurat Penyebaran Corona Virus Disease (Covid-19). https://www.kemdikbud.go.id/main/blog/2020/03/se-mendikbud-pelaksanaankebijakan-pendidikan-dalam-masa-darurat-penyebaran-covid19. Diunduh 30 Maret 2021.

Surat Edaran Kepala Dinas Pendidikan Kota Semarang tentang Layanan Penyelenggaraan Pendidikan dalam Rangka Pencegahan Penularan dan Penyebaran Covid-19 di Kota Semarang.http://disdik.semarangkota.go.id/v15/content/image/files/Surat $\% 20$ Edaran $\%$ 20Lavanan\%20Penvelenggaraan\%20Pendidikan.pdf. Diunduh 30 Maret 2021.

Suyoto. 2010. "Galakkan Baca Buku untuk Kemajuan Bangsa". Media Indonesia Mei, hal 12. https://mediaindonesia.com/. Diunduh 30 Maret 2021.

Undang-Undang No. 20 Tahun 2003 tentang Sistem Pendidikan Nasional. https://pusdiklat.perpusnas.go.id. Diunduh 30 Maret 2021.

Utami, Larasati Diyah. 2021."Tingkat Literasi Indonesia di Dunia Rendah, Rangking 62 Dari 70 Negara". https://perpustakaan.kemendagri.go.id/?p=4661. Diunduh 9 April 2021. 